\title{
A NEW AULACIDEA SPECIES (HYMENOPTERA, CYNIPIDAE) FROM CABO DE GATA NATURE PARK (SPAIN) INDUCING GALLS ON LAUNAEA ARBORESCENS, INCLUDING DESCRIPTION OF ITS TERMINAL INSTAR LARVA
}

\author{
J. L. Nieves-Aldrey*
}

\begin{abstract}
A new species of Aulacidea Ashmead, A. martae n. sp. (Hymenoptera, Cynipidae) is described from Cabo de Gata Nature Park (South-Eastern Spain). The new species induces galls on stems of Launaea arborescens (Asteraceae) and represents the first cynipid species recorded from this plant, growing in desertic areas of south Spain. The terminalinstar larva and the gall are also described. A. martae is closely related to A. laurae Nieves-Aldrey, a species inducing galls in achenes of Podospermum laciniatum (Asteraceae). Characters separating adults, larvae and galls of both species are given and life-cycle data of the new species are provided.

Key words: Aylacini, Aulacidea, herb gall-wasps, new species, Launaea, galls, Cabo de Gata, Spain.
\end{abstract}

\section{RESUMEN}

Una nueva especie de Aulacidea (Hymenoptera, Cynipidae) del parque natural de Cabo de Gata (España) que induce agallas en Launaea arborescens, incluyendo la descripción de su último estadio larval

Se describe una nueva especie de Aulacidea Ashmead: A. martae sp. n. (Hymenoptera, del Parque Natural de Cabo de Gata (Sureste de España). La nueva especie induce agallas en tallos de Launaea arborescens (Asteraceae) y es la primera especie de cinípido citada en esa planta, que crece en áreas desérticas del sureste español. Se describe también la larva madura y la agalla. A. martae es cercana a $A$. laurae Nieves-Aldrey, una especie que forma agallas en los aquenios de Podospermum laciniatum (Asteraceae). Se señalan los caracteres de adultos, larvas y agallas que permiten la separación de las dos especies y se aportan datos sobre el ciclo de vida de la nueva especie.

Palabras clave: Aylacini, Aulacidea, avispas gallícolas, hierbas, especie nueva, Launaea, agallas, Cabo de Gata, España.

\section{Introduction}

Generally speaking the Cynipidae (Hymenoptera, Cynipoidea) can be divided into two groups: the oak gall wasps, the largest fraction associated with
Fagaceae, mainly Quercus, and the herb gall wasps whose representatives induce galls in herbs of the families Asteraceae, Lamiaceae, Papaveraceae, Rosaceae Apiaceae and Valerianaceae. The herb gall wasps are currently classified within the Aylacini, a

* Museo Nacional de Ciencias Naturales, Departamento de Biodiversidad y Biología Evolutiva. C/José Gutiérrez Abascal 2, 28006 MADRID, ESPAÑA. E-mail: aldrey@mncn.csic.es 
Table 1.- The Palaearctic species of Aulacidea.

Tabla 1.-Especies paleárticas de Aulacidea.

\begin{tabular}{|c|c|}
\hline Species of Aulacidea & host plant \\
\hline A. abdominalis (Thomson, 1877) & $?$ \\
\hline A. acroptilonica Tyurabaev, 1979 & Acroptilon \\
\hline A. andrei (Kieffer, 1900)* & Hypochaeris \\
\hline A. arnicae Hoffmeyer, 1930 & Arnica \\
\hline A. ascanica Dyakontshuk, 1988 & Serratula \\
\hline A. discolor Dyakontshuk, 1988 & Echinops, Centaurea \\
\hline A. follioti Barbotin, 1972 & Sonchus \\
\hline A. freesei Nieves-Aldrey, 1995 & Silybum \\
\hline A. hieracii (Bouché, 1834) & Hieracium \\
\hline A. kiefferi Cotte, 1915 * & $?$ \\
\hline A. koelpiniae Dyakontshuk, 1988 & Koelpinia \\
\hline A. laurae Nieves-Aldrey, 1992 & Podospermum \\
\hline A. lutigea Dyakontshuk, 2003* & Atriplex? \\
\hline A. nibletti Quinlan \& Askew, 1969 & Hieracium \\
\hline A. parvula Dyakontshuk, 1984 & Eryngium, Echinops, Cousinia, Centaurea \\
\hline A. phlomica Belizin, 1959 & Phlomis \\
\hline A. pilosellae (Kieffer, 1901) & Hieracium \\
\hline A. pumila (Giraud, 1859) * & $?$ \\
\hline A. rubi Dyakontshuk, 2003 & Rubus? \\
\hline A. schlechtendali (Rübsaamen, 1896) * & Hieracium \\
\hline A. scorzonerae (Giraud, 1859) & Scorzonera \\
\hline A. serratulae Dyakontshuk, 1981 & Hieracium \\
\hline A. subterminalis Niblett, 1946 & Hieracium \\
\hline A. tobiasi Melika, 2004 & Saussurea \\
\hline A. tragopogonis (Thomson, 1877) & Tragopogon \\
\hline A. verticillica Belizin, 1959 & Salvia \\
\hline
\end{tabular}

$(*)$ indicates taxa of dubious status

tribe that, as far as is known, constitutes a para and/or polyphyletic assemblage of taxa and needs a rearrangement of its actual classification (Liljeblad \& Ronquist, 1998; Ronquist \& Liljeblad, 2001; Nieves-Aldrey, 2001; Nylander et al, 2004; Nylander, 2004). About 160 species are known worldwide, 123 of them are recorded from the Palaearctic (Liljeblad, 2002), and 35 from Spain (Nieves-Aldrey, 2001; Nieves-Aldrey et al., 2004).

The genus Aulacidea was erected by Ashmead (1897) for the nearctic species A. harringtoni, a species inducing galls in stems of Mulgedium and Lactuca (Asteraceae). Morphologically the genus can be distinguished from other Aylacini by a combination of characters: a closed marginal cell in the forewing and a striate mesopleuron. Aulacidea comprises 33 species worldwide; of these 26 have a palaearctic distribution. However I consider 5 of these last as species of dubious status (see Table I). Most species of Aulacidea induce galls on plants of the family Asteraceae with the exception of two species recorded from Lamiaceae (genera Salvia and Phlomis) and another from Eryngium (Apiaceae). Recently two Aulacidea species have been described from the steppe of Ukraine, one from galls on Rubus idaeus L., and another galling stems of Atriplex sp (Diakontschuk, 2003). Both the identification of the host plant of the former and the generic adscription of the later have been questioned (Melika, 2004).

Collecting surveys of herb gall wasps across Spain in recent years have produced findings of new species or interesting records of Aylacini (Nieves-Aldrey, 2001，2003a，2003b; NievesAldrey \& Parra, 2003; Nieves-Aldrey et al., 2004). Large areas of Spain remain poorly studied and exploration in search of herb gall wasps is potentially rewarding. Confirming this prediction we have just found some new aylacini species that will be described elsewhere. One of these species was 
found in the protected area of Cabo de Gata (Almería), south-eastern Spain. The new species, belonging to the genus Aulacidea, was found galling Launaea arborescens (Batt.) (Asteraceae) an endemic plant of arid areas of south Spain and North Africa. Abundant galls and larvae of the new species were collected and adults were reared from the galls. Adults, galls and last-instar larvae of the new species are described here.

\section{Material and methods}

The studied material of Aulacidea martae is listed below. Adult females were dissected in $70 \%$ ethanol, air dried, mounted on a stub and coated with gold, and pictures were taken with a scanning electron microscope FEI QUANTA 200 (high vacuum technique) for several standardised views. Forewings were mounted in euparal on slides, and later checked under a stereomicroscope. Larvae were transferred directly from absolute alcohol onto a SEM-stub and into the microscope at low vacuum, without prior fixation or coating. However, mandibles were dissected, mounted and observed as morphological parts of the adult. Pictures of the forewing and galls were taken with a digital camera attached to a Leica stereomicroscope. Morphological structures and abbreviations follow Ronquist \& Nordlander (1989), Ronquist (1995a, b), Liljeblad (2002) and Nieves-Aldrey (2001). SEM pictures of adults and larva have been deposited in Morphbank (http://morphbank.net) [Accesion numbers to be assigned].

All adult insects were reared from galls collected in the field, and then kept under indoor laboratory conditions until emergence of adults.

\section{Aulacidea martae n. sp.}

(Figs. 1-4)

Type Material. Holotype female (in Museo Nacional de Ciencias Naturales, Madrid, card mounted, SPAIN, Almería, Natural Park of Cabo de Gata, S. José, Playa de los Genoveses, $36^{\circ} 44.592 \mathrm{~N} 002^{\circ} 07.382 \mathrm{~W}, 16 \mathrm{~m}$; ex cryptic gall in twigs of Launaea arborescens (Asteraceae), gall collected on 8/I/2004, insect emerged II/2004, J. L. Nieves-Aldrey leg. Paratypes: 20 우 오, same data as holotype, in Museo Nacional de Ciencias Naturales, Madrid (catalogue number 9559).

DESCRIPTION. Female (Fig. 3E). Body length, measured from anterior margin of head to posterior margin of metasoma, $1.8-2.1 \mathrm{~mm}(\mathrm{~N}=21)$. Coloration predominantly black; head and mesoso- ma entirely black; metasoma reddish to dark brown; antennae and legs light brown, excepting basal half of coxae, last tarsomere, two first antennomeres and apex of flagellum, dark brown to black.

\section{Head}

Head, dorsal view about two times as wide as long. POL as long as OOL, posterior ocellus separated from inner orbit of eye by about 1.9 times its diameter.

In anterior view (Fig. 1A) more or less trapezoid shaped; 1.2 times as broad as high; lower face coriarious and weakly pubescent; facial striae radiating from clypeus almost reaching ventral margin of compound eyes; lower face medially without striae. Upper face and vertex almost hairless, with more weak coriarious sculpture. Ocellar plate distinctly raised. Lateral margin of gena slightly bowed, malar space about 0.6 times the height of compound eye. Clypeus more or less quadrate, ventral clypeal margin straight or weakly bowed, not projecting over mandibles. Anterior tentorial pits conspicuous. Epistomal sulcus and clypeo-pleurostomal lines indistinct. Antennal sockets situated slightly below mid-height of compound eye; distance between antennal rim and compound eye as long as width of antennal socket including rim.

Occiput moderately pubescent, excepting a hairless area around the dorsal and lateral parts of occipital foramen; with weak coriarious sculpture (fig. 1B), without occipital carina. Gular sulci indistinct; median hairy strip of gula narrow. Distance between occipital and oral foramina as long as height of occipital foramen. Oral foramen about 2 times as long as occipital foramen.

Mouthparts. Mandibles strong, almost completely exposed, not hidden by ventral projection of clypeus; right mandible with three teeth; left with two teeth. Maxillary stipes long, about three times as long as broad, reaching base of labial palps. Maxillary palp with five segments: first segment very short, as broad as long; second to fourth segments about twice as long as broad; fifth nearly twice as long as fourth. Prementum more or less rectangular but with lateral margins slightly diverging ventrally. Labial palp with three segments: first and third segments subequal in length, second segment about 0.5 times as long as first and third.

Antennae, female (Fig. 1C); 0.7 times as long as body, with 13 antennomeres; flagellum not broadened to apex. Elongate placodeal sensilla present on all flagellomeres excepting first and second; they are disposed in one single row, each placodeal sensillum extending from base to apex of flagellome- 

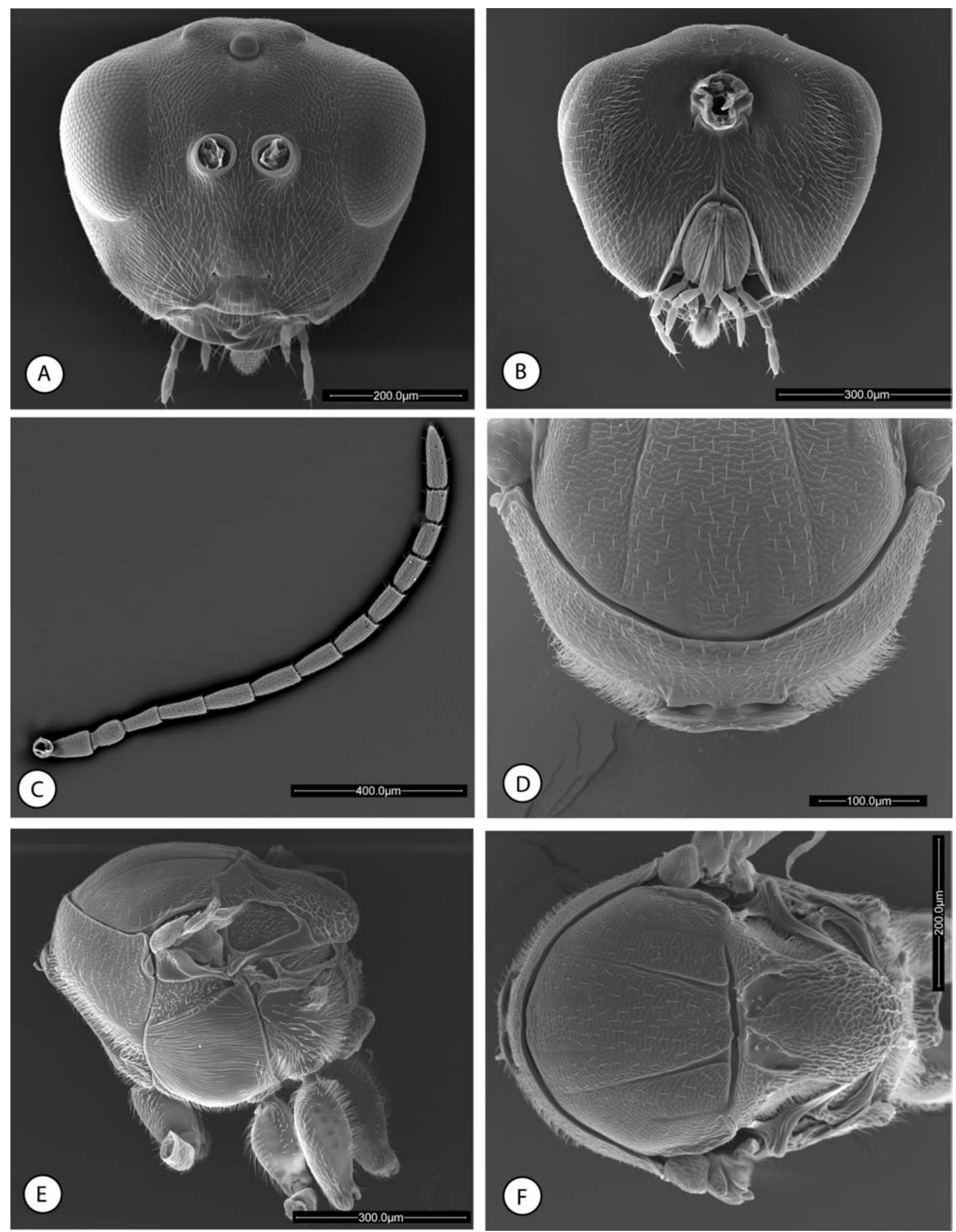
re. Antennal pores are visible near apex on last flagellomeres and two on last flagellomere. Scape 1.2 times as long as pedicel; with very weak alutaceous sculpture; pedicel with imbricate sculpture, almost as long as F1. F1 slightly broadened to apex, 2.1 times as long as broad and 0.8 times as long as F2;. F2 to F4 subequal; F5 to F10 progressively decreasing in length. Ultimate flagellomere 3 times as long as broad and 1.8 times as long as penultimate.

\section{Mesosoma}

Pronotum, female (Fig. 1D).- Length of pronotum medially (= shortest distance between dorsal and anterior margins) moderately long (high); in lateral view, ratio of length to width of pronotum (measured near mesopleural spiracle) $=0.45$. Admedian pronotal depressions oval transverse, deep, open laterally, separated medially by a distance almost as broad as a half of an admedian depression. Posterior pronotal plate rectangular, sculptured and hairy as others parts of the pronotum; ventral and lateral margins weakly marked. Lateral surface of pronotum weakly coriarious and slightly pubescent. Spiracular incision of pronotum distinct.

Mesonotum (Fig. 1E, 1F). Mesoscutum 1.3 times as wide as long; with weak coriarius sculpture and weakly pubescent. Median mesoscutal impression very weakly impressed in posterior one ninth of mesoscutum. Notauli complete but weakly impressed in anterior one third of mesoscutum. Anteroadmedian signa very shallowly impressed, almost indistinct. Mesoscutum and scutellum separated by a distinct transscutal fissure. Scutellar foveae smooth and shallow, ovate elongated posteriorly, measuring about one third as long as scutellum; separated anteriorly by a narrow septum; their inner posterior margins strongly diverging posteriorly. Scutellum in dorsal view about 0.8 times as long as mesoscutum; in lateral view, extending posteriorly slightly past dorsellum. Dorsal surface of scutellum, regularly reticulate rugose. Axillula smooth and slightly pubescent. Posterodorsal and posterior margins of axillula distinct.

Mesopleuron beneath mesopleural triangle thoroughly longitudinally costulate, almost glabrous.
Mesopleural triangle distinctly impressed and pubescent; their dorsal and ventral margins clearly marked.

Metanotum (Fig. 2A). Metascutellum conspicuously constricted medially. Bar ventral to metanotal trough almost smooth. Metanotal trough narrow and densely pubescent.

Metapectal-propodeal complex. Metapleural sulcus meeting anterior margin of metapectal-propodeal complex about at mid-height of latter. Lateral propodeal carinae parallel, slightly narrower posteriorly. Lateral and median propodeal area smooth and densely pubescent. Nucha dorsally with strong irregular costulae.

Legs. Tarsal claws simple, without a basal lobe or tooth.

Forewing (Fig. 2F). As long as body, hyaline. Marginal cell closed along anterior margin; 2.4 times longer than wide; radius (Rs) slightly bowed. Areolet distinct. Hair fringe along apical margin long.

\section{Metasoma}

Female metasoma (Fig. 2B). In lateral view 1.3 times as long as high. Third abdominal tergum covering about one fourth of metasoma, about 0.8 times as long as fourth; antero-medial area of third abdominal tergum with a hair patch. Fourth to seventh terga smooth and nude, except for a posterior strip of weak micropunctutes. Projecting part of hypopygial spine short, shorter than basal height of spine; ventrally with two rows of short hairs.

TERMINAL-INSTAR LARVA. Larvae hymenopteriform, with clear segmentation and no appendages. Body in ventral view more or less fusiform, ventrally curved. Coloration yellowish and body smooth, with only very few short setae in the head region. Dimensions, $3.4 \mathrm{~mm}$ length, $2.2 \mathrm{~mm}$ in breadth. Body composed of head and 13 segments (Fig. 2C). First segment, in ventral view, not narrowed medially under ventral part of head, laterally with two pairs of short setae and dorsollaterally with a few short setae; segments two to eleven of similar length but progressively narrower; last segment truncate at apex. Head (Fig. 2D) more or less rounded, broader dorsally; vertex slightly concave.

Fig. 1.- Aulacidea martae n. sp, female (SEM). A) Head anterior view. B) Head posterior view. C) Antenna. D) Pronotum anterior view. E) Mesosoma lateral view. F) Mesosoma dorsal view.

Fig. 1.- Aulacidea martae n. sp, hembra (SEM). A) Vista anterior de la cabeza. B) Vista posterior de la cabeza. C) Antena. D) Vista anterior del pronoto. E) Vista lateral del mesosoma . F) Vista dorsal del mesosoma. 

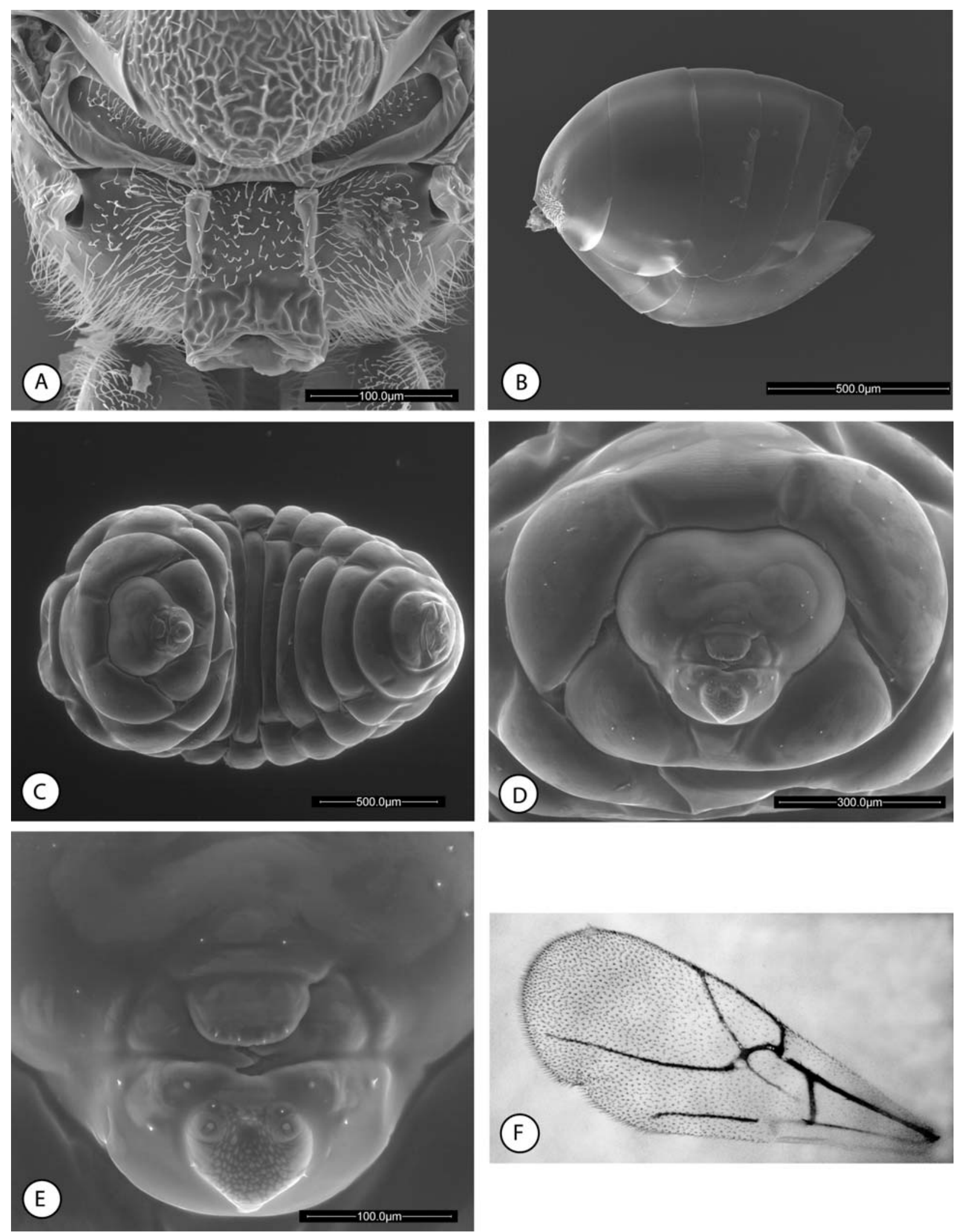

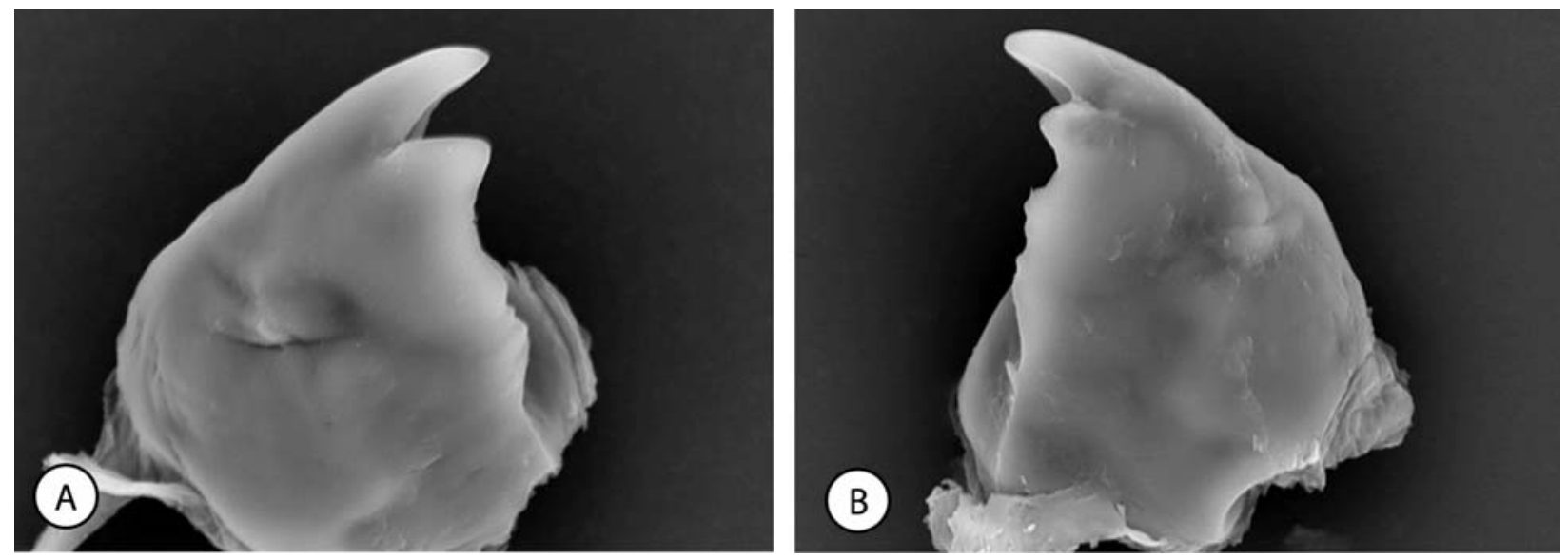

Fig. 3.- Mandibles of terminal larvae. A) Left mandible. B) Right mandible.

Fig. 3.- Mandíbulas izquierda (A) y derecha (B) de la larva de último estadio.

Antennal areas and antennae indistinct; antennal and genal setae present.

\section{Mouth parts (Fig. 2E)}

Clypeus well marked, triangular; ventral part of clypeus sub-rectangular; its ventral margin straight; pair of supraclypeal setae present. Labrum more or less rectangular with rounded sides, covering only part of the apices of the mandibles. Maxillae are triangular and bear a pair of maxillary palps and a pair of short setae. Labium more or less rhomboidal; pair of labial palps and labial setae conspicuous. Labial area surrounding the salivary orifice with a conspicuous tuberculate pattern. Mandibles (Fig. $3 \mathrm{~A}, \mathrm{~B}$ ) are more or less symmetrical, without sculpture or hairs; only the bases of the mandibles are visible underneath the labrum. In anterior view the right mandible (Fig.3B) and the left mandible (Fig. $3 \mathrm{~A})$ present two teeth, one apical, bigger and acute, and another secondary, smaller.

Eтymology. Named after my daughter Marta.

GALL (Fig. 4A-D). Galls are formed inside stems and twigs of Launaea arborescens (Fig. 4A). Galls are completely cryptic, not causing any stem swelling. However old galls can be detected by the exit holes of the gall inducer or parasitoids (Fig. 4B). Larval cells are ellipsoid measuring about $3 \mathrm{~mm}$ long (Fig. 4C, 4D). Galls were fully developed, and the larvae mature, in January when collected. By February the larvae pupate under laboratory conditions and the cynipids started to emerge. The host plant, Launaea arborescens (Batt.) is a perennial shrub reaching a height of 50-150 cm (Sagredo, 1987) growing in a semi-desertic area of South Spain (Fig. 4F). The plant flourishes throughout the year although more abundant flowering occurs from May to August. The mean annual rainfall at the collecting site is $178 \mathrm{~mm}$ (period 1950-74) of which $79 \%$ falls from October to March.

LIFE CYCLE. The life cycle is univoltine with a single brood synchronised with its annual host plant. Adult gall-wasps (Fig. 4E) emerge in February. This relatively early emergence compared with other Aulacidea species is not strange given the climate of its habitat, a desert area, at sea level, with very mild and temperate winters. Most Aulacidea species are univoltine with a single

Fig. 2.- Aulacidea martae n. sp, adult female and terminal larva (SEM). A) Propodeum. B) Metasoma lateral view. C) Larva, ventral view of the body. D) Larva, anterior view of the head. E) Larva, anterior view of mouth parts. F) Adult, left forewing (LM).

Fig. 2.- Aulacidea martae n. sp, hembra adulta y último estadio larval (SEM). A) Propodeo. B) Vista lateral del metasoma. C) larva, vista ventral del cuerpo. D) larva, vista anterior de la cabeza. E) larva, vista anterior de las estructuras bucales. F) adulto, ala anterior izquierda (LM). 

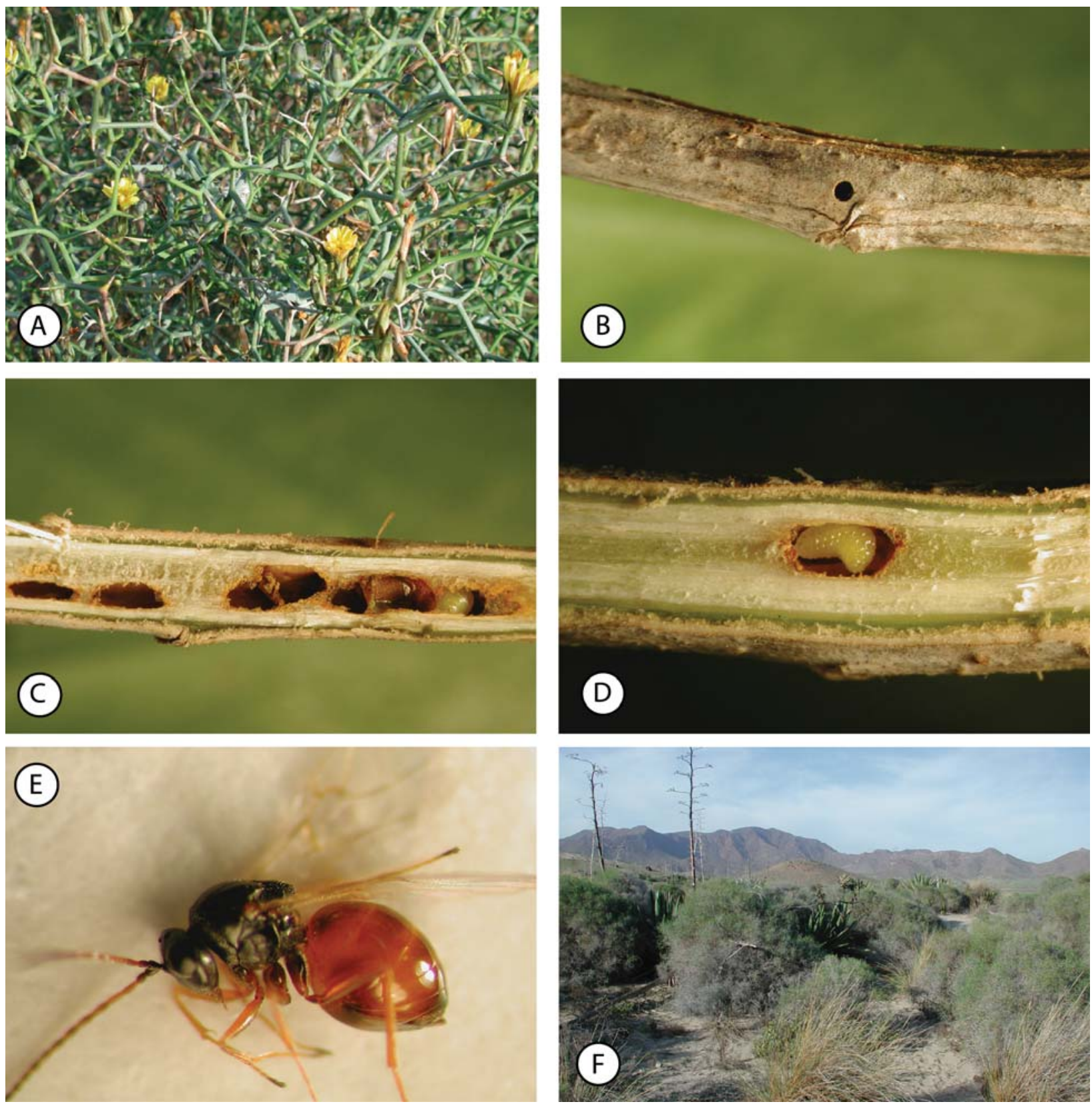

Fig. 4.- Aulacidea martae n. sp. A) Host plant, Launaea arborescens. B) Galled twig with an emergence hole. C) Longitudinal section of a galled twig. D) A single larval cell with a terminal larva. E) Adult female. F) Collecting site at Playa de los Genoveses, Cabo de Gata, Almería (Spain)

Fig. 4.- Aulacidea martae n. sp. A) Planta hospedadora, Launaea arborescens. B) Ramita con agalla provista del orificio de emergencia. C) Sección longitudinal de una ramita con agalla. D) Única célula larvaria con una larva de último estadio. E) Hembra adulta. F) Lugar de recolección en la Playa de los Genoveses, Cabo de Gata, Almería (Spain). 
generation synchronised with their annual host plants. However the host plant of Aulacidea martae is a perennial shrub and it could be possible that two or more generations of the gall inducer would occur in a host plant flowering throughout the year. It should be emphasized, however, that we do not have field data supporting this hypothesis. All reared specimens were females suggesting a parthenogenetic or thelytokous parthenogenetic generation. This type of reproduction has been recorded for other Aulacidea species. Adult cynipid emergence does occur after February. Presumably insects overwinter as larvae inside the galls and pupate in winter.

DistriBUtion. The new species is presently known only from the Natural Park of Cabo de Gata, Almería, Spain. However it is possible that more sampling effort could result in finding the species in other parts of the area of distribution of its host plant. Launaea arborescens is a plant indigenous to the semi-desert of south-eastern Spain but is a Saharo-Canarian phytogeographical element also present in vast areas of North Africa and the Canary Islands.

\section{Discussion}

DiAgNOSIS AND IDENTIFICATION. Closely related to Aulacidea laurae Nieves-Aldrey and Aulacidea follioti Barbotin. In common with these species A. martae has a first flagellar segment distinctly shorter than the second and narrow, elongated and widely separated scutellar foveae.

The adults of the new species differ from $A$. laurae as follows (to be added to the identification keys in Nieves-Aldrey, 2001).

- Coloration entirely yellow red or black. Mesosoma not contrasting in colour with metasoma. Radial cell relatively longer; about 2.6-6 times as long as broad. Apical hair fringe of forewing short. Head in anterior view higher and narrower. Median mesoscutal impression relatively longer and well impressed in posterior one third of mesoscutum. Normal bisexual reproduction. Galls in achenes of Podospermum laciniatum

Aulacidea laurae

- Mesosoma black, contrasting in colour with metasoma that is reddish. Radial cell of forewing relatively shorter; about 2-5 times as long as broad. Apical hair fringe long. Head in anterior view not as high and broader. Median mesoscutal impression relatively shorter and more shallowly impressed in posterior one third of mesoscutum. Males unknown. Parthenogenetic reproduction. Galls on stems of Launaea arborescens

Aulacidea martae sp. $\mathrm{n}$
For the respective galls the differences of the new species with $A$. laurae and $A$. follioti can be stated as follows:

1. Galls cryptic; single ellipsoidal cells inside stems of Launaea arborescens Aulacidea martae sp. $\mathbf{n}$.

- Galls visible externally .....

2. In achenes of Podospermum laciniatum

In stems of Sonchus asper Aulacidea laurae Aulacidea follioti

\section{ACKNOWLEDGEMENTS}

I thank Laura Tormo for technical assistance with SEM photomicrographs. Revising the manuscript and improving English by Graham Stone and Georges Melika is greatly acknowledged. Financial support was provided by the Spanish Ministry of Science and Technology, research project REN2002-03518/GLO.

\section{References}

AsHMEAD, W. H., 1897. Descriptions of some new genera in the family Cynipidae. Psyche, 8: 67-69.

DiakontshuK, L. A., 2003. [New and little known species of cynipids (Hymenoptera, Cynipidae) from Ukraine.] Vestnik zoologii, 37(2): 9-16 (in Russian).

Liljeblad, J., 2002. Phylogeny and Evolution of Gall Wasps (Hymenoptera: Cynipidae). Doctoral dissertation. Department of Zoology, Stockholm University.

LilJeblad, J. \& RonQuist, F., 1998. A phylogenetic analysis of higher-level gall wasp relationships (Hymenoptera: Cynipidae). Systematic Entomology, 23: 229-252.

MeliKA, G., 2004. A new species of gall wasp from the Russian Far East (Hymenoptera: Cynipidae, Aylacini). Proceedings of the Russian Entomological Society, 75(1): 214-218.

Nieves-Aldrey, J. L., 2001, Hymenoptera, Cynipidae. In: Ramos M.A. et al. (eds) Fauna Ibérica, vol. 16, Museo Nacional de Ciencias Naturales (CSIC), Madrid. 636 pp.

Nieves-Aldrey, J. L., 2003a. Descubrimiento de la agalla y ciclo biológico de Neaylax versicolor (NievesAldrey) (Hymenoptera, Cynipidae): primer registro de un cinípido asociado a plantas papaveráceas del género Fumaria. Boletín de la Sociedad entomológica Aragonesa, 32: 111-114.

Nieves-Aldrey, J. L., 2003b. Primera cita para España de Timaspis urospermi (Kieffer), con notas taxonómicas y biológicas, incluyendo la descripción de la larva (Hymenoptera, Cynipidae, Aylacini). Boletín de de la Sociedad entomológica Aragonesa, 33: 79-83. 
Nieves-Aldrey, J. L. \& PARrA, L. A., 2003. A new species of Isocolus (Hymenoptera, Cynipidae) from Spain, inducing galls in flower heads of Leuzea conifera (Asteraceae). Annales de la Société entomologique de France, 39(1): 49-54.

Nieves-Aldrey, J. L., Gómez, J. F. \& Hernández Nieves, M., 2004. Nuevos datos sobre Aulacidea freesei y Phanacis zwoelferi (Hymenoptera, Cynipidae, Aylacini), inductores de agallas en Silybum marianum (Asteraceae), en la Península ibérica, incluyendo la descripción y comparación de sus larvas terminales y sus agallas. Boletín de de la Sociedad entomológica Aragonesa, 34: 85-93.

Nylander, J. A. A., 2004. Bayesian phylogenetics and the evolution of gall wasps. Ph. D. Thesis. University of Uppsala. Uppsala.

Nylander, J. A., Ronguist, F., Huelsenbeck, J. P. \& NiEves-Aldrey, J. L., 2004. Bayesian Phylogenetic Analysis of Combined Data. Systematic Biology, 53(1): 47-67.

RONQUisT, F., 1995a. Phylogeny and early evolution of the Cynipoidea (Hymenoptera). Systematic Entomology, 20: 309-335.

RONQUIST, F., 1995b. Phylogeny and classification of the Liopteridae, an archaic group of cynipoid wasps (Hymenoptera). Entomologica scandinavica Supplement, 46: 1-74.
RonQuist, F. \& LILJEBLAD, J., 2001. Evolution of the gall wasp-host plant association. Evolution, 55(12): 2503-2522.

Ronquist, F. \& Nordlander, G., 1989. Skeletal morphology of an archaic cynipoid, Ibalia rufipes (Hymenoptera: Ibaliidae). Entomologica scandinavica Supplement, 33: 1-60.

SAgredo, R., 1987. Flora de Almería. Plantas vasculares de la provincia. Instituto de Estudios Almerienses. Almería. 552 pp.
Recibido, 3-IX-2004 Aceptado, 29-XI-2004 Publicado, 31-XII-2004 